Article

\title{
Justice for All in the Americas? A Quantitative Analysis of Admissibility Decisions in the Inter-American Human Rights System
}

\author{
Simon Zschirnt
}

check for

updates

Citation: Zschirnt, Simon. 2021. Justice for All in the Americas? A Quantitative Analysis of Admissibility Decisions in the Inter-American Human Rights System. Laws 10: 56. https:// doi.org/10.3390/laws10030056

Received: 29 April 2021

Accepted: 29 June 2021

Published: 4 July 2021

Publisher's Note: MDPI stays neutral with regard to jurisdictional claims in published maps and institutional affiliations.

Copyright: (C) 2021 by the author. Licensee MDPI, Basel, Switzerland. This article is an open access article distributed under the terms and conditions of the Creative Commons Attribution (CC BY) license (https:/ / creativecommons.org/licenses/by/ $4.0 /)$.
Department of Social Sciences, Texas A\&M International University, Laredo, TX 78041, USA; simon.zschirnt@tamiu.edu

\begin{abstract}
The overwhelming majority of unsuccessful petitions in the Organization of American States' Inter-American human rights system are unsuccessful because they are dismissed at the pre-admissibility or admissibility phase rather than at the merits phase. Although this preliminary screening of applications constitutes the major obstacle to petitioners seeking justice, there has been relatively little scholarly analysis of the potential interplay of legal and attitudinal factors at this phase. That is, whether this phase may be where the biases that the system has been accused of (i.e., bias against leftist regimes and a "hierarchization" of negative rights and liberties over social justice) manifest themselves. This article fills this gap in the literature by undertaking a comprehensive quantitative analysis of Inter-American Commission on Human Rights admissibility decisions that measures the impact of a broad range of factors and compares the dynamics of admissibility decisions with those of merits decisions. In so doing, it places into context backlash against the system that has led to recent changes in the system's procedures.
\end{abstract}

Keywords: Organization of American States; Inter-American human rights system; Inter-American Commission on Human Rights; admissibility

\section{Introduction}

The Inter-American human rights system has been acknowledged as "one of the most effective parts of the otherwise largely moribund Organization of American States (OAS)" (Biron 2013), having developed over its more than 60-year history into a "quasiconstitutional regime with wide recognition of its binding jurisdiction and a respectable compliance record" (Oquendo 2017, p. 2). Responsible for enforcement of the American Convention on Human Rights, the American Declaration of the Rights and Duties of Man, and other OAS human rights treaties, the Inter-American system, along with the African and European systems, is one of only three regional human rights systems in which supranational tribunals are empowered to adjudicate individual complaints against states. With jurisdiction over a region that continues to see "systematic, targeted executions and forced displacement by paramilitary groups ... death squad and police killings ... military abuses and the use of torture to extract confessions ... [and] pervasive extrajudicial violence" (Cavallaro and Brewer 2008, p. 785), the system has been credited with "holding past administrations accountable for human rights violations and setting a higher standard for the treatment of people by the state in Latin America" (Council on Hemispheric Affairs 2012).

However, the system has in recent years entered what some have called a "lifethreatening crisis" (Oquendo 2017, p. 2). In particular, it has begun to face an unprecedented degree of state backlash. This has primarily taken the form of accusations of bias against leftist regimes challenging American hegemony in the region, such as those in Bolivia, Nicaragua, and Venezuela, and calls for fundamental change to the system. The system, critics have claimed, has "been geared away from safeguarding human rights and 
liberties towards acting more like America's voice in the region", aggressively scrutinizing the human rights records of America's adversaries while mostly giving a pass to its allies (Holmund 2014). Relatedly, the system has also been accused of "dictating a hierarchy of rights" in which negative rights and liberties such as freedom of expression are given undue precedence to the detriment of equally important economic, social, and cultural rights (Holmund 2014). While the OAS has attempted to placate its critics in a variety of ways, most notably by launching a "strengthening" process that led to several changes in the system's procedures, the backlash has persisted and even spread to other states.

This article tests the assumptions behind this backlash by examining through quantitative analysis of the system's admissibility jurisprudence whether there is any validity to the accusations of political bias and "hierarchization" of rights that led to those changes and may produce further changes still. Expanding upon previously published research that was confined to analysis of merits decisions (Zschirnt 2017), it extends the analysis to the admissibility phase, which is the phase in the processing of petitions at which most unsuccessful petitions are dismissed. The article proceeds as follows: Section 2 provides a brief overview of the Inter-American system and its procedures, with particular emphasis on the admissibility phase, Section 3 examines the backlash and accusations of bias against the Inter-American system, Section 4 outlines the research methodology used to evaluate these accusations, Section 5 discusses the results, and Section 6 discusses their implications for the system's future.

\section{The Inter-American System in Brief}

The Inter-American human rights system is comprised of two institutions: the InterAmerican Commission on Human Rights (IACHR) and the Inter-American Court of Human Rights (IACtHR). The quasi-judicial IACHR is the decision-maker of first instance in the system and is responsible for the initial processing of petitions. This processing consists of two phases: the admissibility phase and the merits phase. At the admissibility phase, if a petition complies with technical and procedural requirements and the IACHR decides that the facts alleged in the petition, if true, would constitute human rights violations, it will declare the petition admissible. Due to time constraints, the seven commissioners' involvement in this phase largely consists of ratifying draft admissibility and inadmissibility reports prepared by the staff attorneys from the OAS's secretariat, often without reviewing the petitions themselves. This is potentially problematic given the biases that have been observed in the secretariat, where the assignment of attorneys to regional groups means that "some attorneys develop either positive or negative views about particular states in their group" (Shelton 2015, p. 9).

If a petition is declared admissible, the IACHR will attempt to mediate a friendly settlement between the petitioner(s) and the state in question. Since the adoption of the IACHR's new rules of procedure in 2000, utilization of the friendly settlement procedure has increased significantly, with an average of five to eight settlements now being reached every year (Contesse 2019b). If the parties fail to settle, the case proceeds to the merits phase, where both parties file briefs and the IACHR may hold hearings and/or conduct further investigation. The merits phase ends when the IACHR files a merits report delivering its decision, which will include recommendations to the state in question if it is found responsible for any human rights violations.

If the state does not comply with the IACHR's recommendations, the case will be referred to the IACtHR provided that the state has made the optional declaration recognizing the IACtHR's jurisdiction in contentious cases. If it has not, then the case can proceed no further than the IACHR. Since Venezuela denounced its ratification of the Convention in 2012, there remain 20 states with such an optional declaration in effect. ${ }^{1}$ Although the IACtHR's review of cases referred by the IACHR is formally de novo, more

1 Argentina, Barbados, Bolivia, Brazil, Colombia, Costa Rica, Chile, the Dominican Republic, Ecuador, El Salvador, Guatemala, Haiti, Honduras, Mexico, Nicaragua, Panama, Paraguay, Peru, Suriname, and Uruguay. 
than $99 \%$ of cases have ended with the IACtHR finding the state in question responsible for human rights violations (Arriagada 2015). Unlike IACHR merits decisions, which are recommendations, IACtHR decisions are legally binding on states. However, access to the IACtHR's binding adjudication is extremely limited due to its reliance on referrals. For example, in 2020 the IACtHR delivered only 19 merits decisions, a number dwarfed by the 2448 petitions received that year by the IACHR (Inter-American Commission on Human Rights 2021).

The major reason for this disparity is the admissibility phase. This phase, not the merits phase or adjudication by the IACtHR, has been the major obstacle to petitioners seeking justice. Much as more than $99 \%$ of the cases reaching the IACtHR have resulted in the state in question being found responsible for human rights violations, more than $96 \%$ of the petitions reaching the merits phase have resulted in the state in question being found responsible for human rights violations (Zschirnt 2017). However, the petitions reaching the merits phase represent only a small fraction of the total number of petitions received by the IACHR. For example, only 359 of the 2448 petitions received by the IACHR in 2020 entered the formal admissibility phase (Inter-American Commission on Human Rights 2021). The 2089 that did not, more than $80 \%$ of those received, were summarily dismissed by the IACHR's secretariat during its initial review, an informal pre-admissibility phase at which petitions deemed clearly inadmissible are screened out. Unfortunately, petitions screened out at this phase are not the subject of inadmissibility reports explaining the IACHR's reasons for dismissing them (as petitions dismissed at the formal admissibility phase are). There is no publicly available record of these dismissals, the subject matter of the dismissed petitions, or the reasons for dismissal and the state concerned is not even notified (only the petitioners are notified).

The opacity of the pre-admissibility phase has been widely criticized by stakeholders and the IACHR's Rules of Procedure have since 2000 called for commissioners to become more involved in the process by forming a working group on admissibility to consider the admissibility of petitions between sessions but it has been inactive. ${ }^{2}$ Efforts to involve the commissioners more have also been hampered by the perception that the commissioners are "less qualified, more ideological, and therefore less trustworthy to handle cases than the permanent staff" (Shelton 2015, p. 8). Ultimately, the realities of the IACHR's limited budget and of part-time commissioners who only meet three times a year and are highly dependent upon the secretariat's full-time staff make significant change unlikely (see, e.g., Shelton 2015; Paul 2016; Hampson et al. 2018). Thus, few conclusions can be drawn about the dynamics of the pre-admissibility phase and its potential interplay of legal and attitudinal factors.

However, the formal admissibility phase, where an admissibility or inadmissibility report is published in each case, is more amenable to such analysis. Moreover, it is this phase rather than the merits phase where most of the petitions that pass the secretariat's initial review but are ultimately dismissed are dismissed. Whereas fewer than $4 \%$ of the cases reaching the merits phase ended with all of the claims against the state in question being dismissed, petitions are dismissed at more than twice that rate at the admissibility phase. For example, in 2014 approximately $8 \%$ of the petitions that reached the admissibility phase were declared inadmissible (Hampson et al. 2018). In addition to petitions declared wholly inadmissible, an even larger percentage of petitions are declared partially inadmissible at this stage. That is, some of their claims are declared admissible while others are declared inadmissible.

At least in this regard, the regional human rights system that the Inter-American system is most similar to is the Council of Europe's European human rights system, where the admissibility phase has also been the major barrier to justice. For example, in 2014 83,657 petitions ( $97 \%$ of those received) were declared inadmissible by the European Court

2 Rules of Procedure of the Inter-American Commission on Human Rights (18 March 2013) [hereinafter IACHR Rules], Art. 35. Reprinted in Basic Documents in the Inter-American System. 
of Human Rights (Hampson et al. 2018). In contrast, the dynamics of the other regional system, the African Union's African human rights system, have been quite different. A large majority of petitions have been declared admissible but the number of petitions received has been relatively small due to cultural barriers, an underdeveloped legal profession, and a lack of awareness of legal remedies (see, e.g., Cole 2010; Yerima 2011; Hampson et al. 2018). For example, although $73 \%$ of the petitions received by the African Commission on Human and Peoples' Rights were declared admissible in 2014, on average the Commission has only finalized 17 cases per year (Hampson et al. 2018).

The admissibility phase is the thus the phase at which the biases that the InterAmerican system has been accused of, if they exist, are most likely to manifest themselves. To further illustrate those potential biases, the following section examines the backlash that the system has faced in recent years.

\section{Resistance to the Inter-American System}

The most vociferous criticism of the Inter-American system has come from the Bolivarian Alliance for the Peoples of Our America (ALBA), an alliance of socialist and social democratic states established in 2004 by former Cuban President Fidel Castro and former Venezuelan President Hugo Chávez. ALBA member states Bolivia, Ecuador, Nicaragua, and Venezuela were at the forefront of a rhetorical campaign against the IACHR and IACtHR between 2011 and 2013 that triggered a "strengthening" process culminating in the adoption of a package of changes to the Inter-American system's procedures. ${ }^{3}$ These states assailed the IACHR and IACtHR as politicized institutions that embody a neoliberal ideology that reflects the hegemonic influence of the United States (which is the OAS's major funder) and that has led them to neglect economic, social, and cultural rights and exhibit a general bias against leftist governments. For example, former Ecuadorian President Rafael Correa denounced the IACHR and IACtHR as "vestiges of neoliberalism and neocolonialism" that apply a "double standard" and are "captured by the interests and visions of North America" (Agencia EFE 2016; ANDES 2015). In a similar vein, Venezuela's former ambassador to the OAS denounced the IACHR as a "mafia" running "an inquisition especially against leftist governments" while former Bolivian President Evo Morales called it a "military base of the United States" that has "covered up for dictatorships" (Oquendo 2017, p. 25).

In support of these accusations, the ALBA member states pointed to several acts of omission by the Inter-American system that purportedly reflect both political bias and corrupting American influence, such as the IACHR's failure to issue precautionary measures during the unsuccessful Venezuelan coup d'état attempt of 2002, its failure to do more to condemn the 2009 coup d'état that removed the leftist former President of Honduras Manuel Zelaya, its failure to condemn the British occupation of the Falkland Islands, and its failure to condemn the American embargo of Cuba (Oquendo 2017). They also pointed to discrepancies in the funding and status of the Inter-American system's thematic rapporteurships, which are responsible for monitoring state compliance with OAS human rights treaties in their respective areas. In particular, they pointed to the fact that the Special Rapporteur for Freedom of Expression receives significantly more funding than, for example, the rapporteurships on the rights of women, children, and indigenous peoples and is a full-time rapporteur rather than a member of the IACHR. These inequities have fueled complaints of a "hierarchization" of rights in which negative rights and liberties are given priority over social justice (see Ruiz-Chiriboga 2013a).

Such "hierarchization", it should be noted, is in no way unique to the Inter-American system. Other regional human rights systems, particularly the European system, have also been criticized for not placing economic, social, and cultural rights on par with classic negative rights and liberties. Indeed, the European Convention on Human Rights provides no explicit protection for economic, social, and cultural rights, although the European Court

3 Although Ecuador was a member of ALBA during the "strengthening" process, it withdrew from the alliance in 2018. 
of Human Rights has increasingly incorporated such rights into its broad interpretations of the Convention (see, e.g., Warbrick 2007; Dahlberg 2014; Leijten 2018). However, what has been unique to the Inter-American system is the intensity of the criticism pertaining to this "hierarchization".

Defenders of the Inter-American system have dismissed this criticism as an attempt to deflect legitimate condemnation by the IACHR and IACtHR of the increasingly autocratic nature of some of the regimes governing ALBA member states. As Martin and Rodriguez-Pinzón (2015, p. 810) note, "it was clear that some of the states that instigated the ['strengthening'] process ... had a hidden agenda intended to limit the scope of the Commission's powers". Such skepticism of the motives of the Inter-American system's critics has been bolstered by the subsequent descent of Venezuela, which in 2012 denounced its ratification of the Convention, into constitutional, economic, and humanitarian crisis. Nonetheless, because the attacks on the Inter-American system came from democratically elected governments, they were taken more seriously than previous backlash against the system that came from military dictatorships and led to the OAS launching the "strengthening" process in 2011.

Ultimately, the dialogue that ensued led to procedural changes that were relatively modest. These most notably included more detailed guidelines for the issuing of precautionary measures, which had become a particular point of contention after the IACHR issued precautionary measures in 2011 halting construction of a \$14 billion hydroelectric dam in Brazil due to concerns about the project's negative impact upon indigenous communities. ${ }^{4}$ However, the more sweeping changes proposed by Bolivia, Ecuador, Nicaragua, and Venezuela were rejected. These would have reduced funding for the Special Rapporteur for Freedom of Expression, curtailed or eliminated the IACHR's "protection" activities (i.e., its hearing of petitions that may result in the referral of cases to the IACtHR or the issuing of precautionary measures in cases of imminent harm), and largely confined the IACHR to its "promotion" activities, educational activities intended to increase public awareness of human rights (such as the publication of reports, the organization of conferences and seminars, and meetings with government officials, NGOs, and other stakeholders) (see Contesse 2019a).

In addition to the ideological divide that has driven this controversy, the InterAmerican system has also faced a cultural divide. Specifically, it has faced an "Anglo-Latin divide" as English-speaking states have increasingly resisted a system dominated by Spanish-speaking states (Carozza 2015, p. 153). This has been due to juristic differences, as the system's procedures and judicial philosophy are modeled on the civil law legal systems of Latin America rather than the common law legal systems of North America and the Anglophone Caribbean, to the underrepresentation of Anglophones on the IACHR and IACtHR, and to the contentious issue of the death penalty (Carozza 2015). Whereas the death penalty has been almost completely abolished in Latin America, the United States and the states of the Anglophone Caribbean have retained and to varying extents continue to impose the death penalty. This has led to persistent conflict with the IACHR and IACtHR, which have increasingly "interpret[ed] and appl[ied] the American Declaration and the American Convention in ways tending toward abolition of the death penalty" (Carozza 2015, p. 163). This conflict led Trinidad and Tobago to become the first state to denounce its ratification of the Convention in 1998 (see Concepción 2001) and to the United States "categorically reject[ing]" the idea that the Declaration imposes legally binding obligations on signatory states (Wilson 2002, p. 1160).

Furthermore, even among states that were not previously at the forefront of the backlash against the Inter-American system, there have recently been signs of growing unease with the IACHR and IACtHR's activism (i.e., their increasingly liberal interpretation of the Convention). For example, in 2017 Argentina's Supreme Court flatly refused to

4 Indigenous Communities of the Xingu River Basin, Pará, Brazil v. Brazil, PM 38/10, Inter-Am. Comm'n H.R. (1 April 2011). 
comply with the IACtHR's decision in Fontevecchia and D'Amico v. Argentina ${ }^{5}$ ordering it to revoke a civil judgment against journalists accused of defaming former President Carlos Menem (see also Contesse 2019a). Indeed, there have been recent stirrings of discontent even among some of the most consolidated democracies in the region, states which overall have been the subject of relatively little litigation before the IACHR and IACtHR and which would otherwise seem the least threatened by those institutions' increased activism. In Costa Rica, the seat of the IACtHR, the runner-up in the country's 2018 presidential election pledged to withdraw its acceptance of the IACtHR's jurisdiction if elected following the court's advisory opinion on Gender Identity and Equality and Non-Discrimination of SameSex Couples $^{6}$, which called upon all OAS member states to legalize same-sex marriage and officially recognize the gender identities of trans individuals (see also Carrillo 2018; Contesse 2018, 2019c).

More significantly, in 2014 the constitutional court of the Dominican Republic declared the country's 1999 acceptance of the IACtHR's jurisdiction invalid shortly after the IACtHR's ruling in Expelled Dominican and Haitian People v. Dominican Republic ${ }^{7}$, which condemned the stripping of thousands of Dominicans of Haitian descent of their Dominican nationality (see also Shelton and Huneeus 2015; Soley and Steininger 2018). Although the validity of the constitutional court's decision has been questioned and no further action to denounce the Convention has been taken by the Dominican government, it underscores the fact that backlash against the Inter-American system has been widespread and not confined to a handful of rogue regimes with poor human rights records. Indeed, so widespread is the backlash that recently it has been a coalition of right-wing rather than left-wing regimes attempting to force change to the system. In particular, Argentina, Brazil, Chile, Colombia, and Paraguay released a joint statement in 2019 criticizing the activism of the IACHR and IACtHR and calling for the adoption of the European Court of Human Rights' doctrine of margin of appreciation in order to protect states' "legitimate space of autonomy" (Girardi Fachin and Nowak 2019).

This growing backlash can be attributed to what Helfer (Helfer 2002, p. 1836) calls "overlegalizing human rights". That is, the natural tendency of international human rights regimes to evolve toward higher levels of "obligation, precision, and delegation" than were originally contemplated by state parties (p. 1910). Central to this evolution has been the Inter-American system's embrace of the idea of the Convention as a "living document" whose interpretation "must fulfill the changing needs of protection". 8 This dynamic approach to treaty interpretation has increasingly led the IACHR and IACtHR to interpret the Convention in ways limiting states' discretion when it comes to contentious issues such as abortion, the death penalty, and LGBT rights, where even liberal democracies may have profound disagreements. Increasing the sovereignty costs associated with membership in this way has predictably led to backlash and to some states reconsidering or even terminating their membership. Whether the increased judicial activism that has given rise to this backlash should be viewed with approval or disapproval depends in large part upon whether the accusations of ideological and cultural bias that have been made against the Inter-American system are true.

\section{Research Methodology}

In order to test the veracity of these accusations as well as to assess the extent to which the dynamics of the admissibility phase differ from those of the merits phase, comprehensive statistical analyses of the IACHR's merits and admissibility jurisprudence

5 Fontevecchia and D'Amico v. Argentina, Merits, Reparations, and Costs, Judgment, Inter-Am. Ct. H.R. (ser. C) No. 293 (29 November 2011).

6 Gender Identity and Equality and Non-Discrimination of Same-Sex Couples, Advisory Opinion OC-24/17, Inter-Am. Ct. H.R. (ser. A) No. 24 (24 November 2017).

7 Expelled Dominican and Haitian People v. Dominican Republic, Preliminary Objections, Merits, Reparations, and Costs, Judgment, Inter-Am. Ct. H.R. (ser. C) No. 282 (28 August 2014).

8 Five Pensioners v. Peru, Merits, Reparations, and Costs, Concurring Opinion of Judge Antônio Agusto Cançado Trindade, Inter-Am. Ct. H.R. (ser. C) No. 98 (28 February 2003). 
were conducted. Analysis of the IACHR's merits jurisprudence was based upon a dataset including every published IACHR merits decision through 2020. This is an updated version of a dataset that was the basis of a previously published analysis of merits decisions through 2015 (Zschirnt 2017). The dataset includes cases that were subsequently referred to and adjudicated by the IACtHR but excludes cases that ended in friendly settlements. Analysis of the IACHR's admissibility jurisprudence was based upon a dataset including every published IACHR admissibility decision through 2020. This includes cases in which the IACHR concurrently decided both the admissibility and the merits of the case as well as cases that ended in friendly settlements after being declared admissible. Because IACHR decision-making has been characterized by strong consensual norms (separate concurring or dissenting opinions were filed in less than $5 \%$ of the merits decisions in the merits decision dataset and less than $1 \%$ of the admissibility decisions in the admissibility decision dataset), the units of analysis were the decisions of the IACHR as a whole rather than the individual votes of commissioners. More precisely, the dependent variable in the analysis of the IACHR's merits jurisprudence was the IACHR's decision as to whether or not the state was responsible for the human rights violations that it was accused of. The dependent variable in the analysis of the IACHR's admissibility jurisprudence was the IACHR's decision as to whether or not the claims were admissible. Split merits decisions in which the IACHR found the state responsible for some of the violations that it was accused of but not others received two separate entries in the dataset. The same was true of split admissibility decisions in which the IACHR found some claims admissible and others inadmissible. Because the dependent variables were dichotomous, logistic regression models were used to estimate the effects of the independent variables upon the likelihood of findings of responsibility or admissibility. These included:

\subsection{State Variables}

These variables captured various characteristics of the states accused of human rights violations in these cases that may have affected the likelihood of the claims against those states being declared admissible and of the states being found responsible for the violations alleged. These included measures of states' levels of democratization, human rights protection, and economic development, measures of the ideological orientations of their governments, and cultural/regional variables. Because the IACHR's processing of cases has been slowed by a large backlog of cases caused by inadequate staffing and resources, the average time between a petition being filed and a decision on the merits being reached has been approximately six and a half years (Dulitzky 2013). ${ }^{9}$ Thus, because regimes accused of human rights violations were frequently no longer in power by the time that decisions on admissibility and decisions on the merits were reached, the measures used in each case were from the year that the alleged violations occurred.

\subsubsection{Polity Score}

Polity scores capture states' authority characteristics. Annual scores fall on a 21-point scale ranging from -10 (autocracy) to 10 (full democracy).

\subsubsection{CIRI Human Rights Index Score}

The Cingranelli-Richards (CIRI) Human Rights Dataset provides information on states' respect for 15 internationally recognized human rights. It features two additive indices: the Physical Integrity Rights Index and the Empowerment Rights Index. The Physical Integrity Rights Index measures the incidence of violations such as forced disappearance, extrajudicial killing, political imprisonment, and torture. Scores range from 0 (frequent incidence) to 8 (no incidence). The Empowerment Rights Index measures state respect for rights to electoral self-determination and to freedom of assembly, association, movement,

\footnotetext{
9 The IACHR has recently adopted several measures to expedite the processing of cases. These include increasing the number of staff, strengthening the friendly settlement mechanism, more quickly archiving inactive cases, and reducing the number of requests for observations at the admissibility and merits phases (see Inter-American Commission on Human Rights 2021).
} 
religion, and speech. Scores range from 0 (no respect) to 14 (full respect). For each case, the country-year score on the index providing the best indication of the likelihood of a violation of the rights invoked by the petitioner(s) was used. That is, Physical Integrity Rights Index scores were used in cases involving claims of violations of rights to life, humane treatment, and personal liberty, claims of violations of judicial guarantees and of subjection to ex post facto laws, claims of violations of rights to juridical personality, and claims of violations of the rights of the family and the rights of the child. On the other hand, Empowerment Rights Index scores were used in cases involving claims of violations of rights to freedom of assembly, association, movement, religion, and speech, claims of violations of rights to equality, privacy, and property, and claims of violations of economic, social, and cultural rights. For cases involving multiple claims falling into both groups, Physical Integrity Rights Index scores were generally used because these claims tended to be the primary focus of both the claimants' petitions and the IACHR's admissibility and merits reports. Because the Physical Integrity Rights Index is an 8-point scale and the Empowerment Rights Index is a 14-point scale, scores were standardized using percentage of maximum performance scaling.

Previous analysis of merits decisions found that states scoring higher on the Polity and CIRI indices were significantly less likely to be found responsible for human rights violations (Zschirnt 2017). This is consistent with analyses of petitions filed in the European human rights system and with the United Nations Human Rights Committee, which have found that states with higher levels of democratization and human rights protection have had fewer petitions filed against them and have been less likely to be found responsible for human rights violations when they have been the subjects of petitions (Boyle and Thompson 2001; Cole 2006, 2011).

\subsubsection{Adjusted Per Capita GDP}

For each case, the per capita gross domestic product of the state in question in the year in which the alleged violations occurred (in 2020 US dollars) was used as the measure of the state's level of economic development. Previous analysis of merits decisions found that states with higher per capita GDPs were significantly less likely to be found responsible for human rights violations (Zschirnt 2017). This is consistent with a large body of research linking economic development to democratization and the maintenance of effective systems of human rights protection (see, e.g., Przeworski et al. 2000; Inglehart and Welzel 2005; Epstein et al. 2006).

\subsubsection{Recognition of IACtHR Jurisdiction}

Another potentially relevant variable was whether the state in question had a blanket acceptance of the IACtHR's contentious case jurisdiction in effect at the time of the alleged violations. Although previous analysis of merits decisions found that states that had accepted the IACtHR's jurisdiction were not significantly more or less likely to be found responsible for human rights violations (Zschirnt 2017), there may be a significant relationship between acceptance of the IACtHR's jurisdiction and admissibility decisions. That is, states that have accepted the IACtHR's jurisdiction may take their obligations under the Convention more seriously in ways that are not fully captured by Polity and CIRI Human Rights Index scores and that affect the likelihood of admissible claims being brought against them.

\subsubsection{Left/Right Party Government}

Finally, in order to test for the presence of the sort of political bias that the InterAmerican system has been accused of, the ideological orientations of regimes accused of human rights violations were included in the model. States governed by socialist, social democratic, or other left-wing parties at the time of their alleged human rights violations were categorized as states with a left party government while states governed by Christian democratic or other right-wing parties at the time of their alleged human rights violations 
were categorized as states with a right party government. States governed by centrist parties or non-partisan governments were the excluded reference category. Coding was based primarily upon the World Bank's Database of Political Institutions. Nominally non-partisan but clearly right-wing military regimes, such as the junta that took power in Argentina in 1976, were coded as right party governments. Although previous analysis of merits decisions did not find a significant relationship between the ideological orientation of a state's government and its likelihood of being found responsible for human rights violations (Zschirnt 2017), the dynamics of the admissibility phase, which acts as a more substantial filter for petitions, may differ from those of the merits phase.

\subsubsection{Cultural/Regional Variables}

Because the Inter-American system has not only been accused of political bias but also cultural bias, states' cultural and regional affinities were included in the model. The Americas were divided into three major cultural realms: North America, the Anglophone Caribbean, and Hispanophone Central/South America and Caribbean. North America consists of the United States and Canada, the Anglophone Caribbean consists of all of the Caribbean Basin's predominantly English-speaking states, and Hispanophone Central/South America and Caribbean consists of all the predominantly Spanish-speaking states of the Americas. OAS member states with a predominant language other than English or Spanish were the excluded reference category. Previous analysis of merits decisions found that, despite the financial backing provided by the United States and the perception that the Inter-American system has been a stalking horse for American interests, North American states were actually significantly more likely to be found responsible for human rights violations (Zschirnt 2017).

\subsection{Claim Variables}

These variables captured the types of human rights violations being alleged in each case. Claims were grouped into 11 categories corresponding to the most common types of claims of violations of the American Convention on Human Rights or the American Declaration of the Rights and Duties of Man.

\subsubsection{Personal Integrity Rights}

Personal integrity rights are rights to freedom and bodily integrity. These include the rights to life, humane treatment, freedom from slavery, and personal liberty guaranteed by Articles 4, 5, 6, and 7 of the Convention and Articles 1 and 25 of the Declaration.

\subsubsection{Civil and Political Rights}

Civil and political rights include the rights to freedom of religion, speech, assembly, association, movement, and equal and effective participation in government guaranteed by Articles 12, 13, 15, 16, 22, and 23 of the Convention and Articles 4, 8, 20, 21, 22, and 24 of the Declaration.

\subsubsection{Rights to Juridical Personality}

Rights to juridical personality include the rights to recognition as a person before the law and to the enjoyment of basic civil rights guaranteed by Article 3 of the Convention and Article 17 of the Declaration.

\subsubsection{Rights to Equality}

Rights to equality include the rights to equal protection of the law and against discrimination on account of race, sex, language, creed, or any other factor guaranteed by Article 24 of the Convention and Article 2 of the Declaration. 


\subsubsection{Property Rights}

Property rights include the rights to private property and against uncompensated takings guaranteed by Article 21 of the Convention and Article 23 of the Declaration.

\subsubsection{Privacy Rights}

Privacy rights include the rights to personal honor and dignity and against undue interference with individuals' private lives guaranteed by Article 11 of the Convention and Article 5 of the Declaration.

\subsubsection{Judicial Guarantees}

Judicial guarantees include the guarantees of a fair trial, effective judicial protection, and due process of law found in Articles 8 and 25 of the Convention and Articles 18 and 26 of the Declaration.

\subsubsection{Freedom from Ex Post Facto Laws}

Freedom from ex post facto laws is guaranteed by Article 9 of the Convention, which prohibits convicting anyone of an offense that was not an offense at the time that it was committed or imposing a heavier penalty than was provided for at the time the offense was committed, and Article 26 of the Declaration.

\subsubsection{Rights of the Family}

Rights of the family include the rights to marriage and to protection of the family guaranteed by Article 17 of the Convention and Article 6 of the Declaration.

\subsubsection{Rights of the Child}

Rights of the child include the special measures for the protection of children that are required by their condition as minors under Article 19 of the Convention and Article 7 of the Declaration.

\subsubsection{Economic, Social, and Cultural Rights}

Economic, social, and cultural rights include the obligation of states to progressively realize the economic, social, educational, scientific, and cultural standards set forth in the OAS Charter, which is established by Article 26 of the Convention, and the rights to education, culture, work, leisure time, and social security guaranteed by Articles 12, 13, 14, 15 , and 16 of the Declaration.

\section{Results}

Summary descriptive statistics are reported in Tables 1-13 and the results of the regression analyses are reported in Tables 14 and $15 .{ }^{10}$ The descriptive statistics illustrate the extent to which the admissibility phase has been a more significant barrier to claimants than the merits phase. Whereas $93 \%$ of merits decisions found the state in question responsible for all of the human rights violations that it was accused of (see Table 1), only $68 \%$ of admissibility decisions found all of the claims made against the state in question admissible (see Table 7). Additionally, as indicated by the Pseudo $\mathrm{R}^{2}$ statistics, the regression models perform very well in explaining the behavior of the IACHR, explaining $38 \%$ of the variance in merits decisions and $41 \%$ of the variance in admissibility decisions.

10 Because CIRI Human Rights Index scores are not available for country years before 1981 or after 2011, cases involving alleged human rights violations committed before 1981 or after 2011, while included in the descriptive statistics, were not included in the regression analyses. These cases amounted to $18 \%$ of the entries in the merits decision dataset and $10 \%$ of the entries in the admissibility decision dataset. Also, because Polity scores are not available for the Bahamas, Barbados, Belize, Grenada, and St. Lucia, cases involving these states, although included in the descriptive statistics, were also not included in the regression analyses. These cases amounted to $2 \%$ of the entries in the merits decision dataset and less than $1 \%$ of the entries in the admissibility decision dataset. 
Table 1. Disposition on the Merits of IACHR Cases.

\begin{tabular}{cc}
\hline Decision & No. of Cases (\%) \\
\hline Responsible on all counts & $813(92.6)$ \\
Responsible on some counts, & $38(4.3)$ \\
not responsible on others & $27(3.1)$ \\
Not responsible on all counts & $878(100.0)$ \\
\hline
\end{tabular}

Table 2. Disposition on the Merits of IACHR Cases by Regime Type.

\begin{tabular}{ccc}
\hline & Left Party Government & Right Party Government \\
\hline Decision & No. of Cases (\%) & No. of Cases (\%) \\
\hline Responsible on all counts & $254(91.4)$ & $437(93.2)$ \\
Responsible on some counts, & $15(5.4)$ & $19(4.1)$ \\
not responsible on others & $9(3.2)$ & $13(2.8)$ \\
Not responsible on all counts & $278(100.0)$ & $469(100.0)$ \\
TOTAL &
\end{tabular}

Table 3. Disposition on the Merits of North American IACHR Cases by State.

\begin{tabular}{ccccc}
\hline & $\begin{array}{c}\text { Responsible } \\
\text { on All Counts }\end{array}$ & $\begin{array}{c}\text { Some Counts, } \\
\text { Not Responsible } \\
\text { on Others }\end{array}$ & $\begin{array}{c}\text { Not } \\
\text { Responsible } \\
\text { on All Counts }\end{array}$ & Total \\
\hline State & $\begin{array}{c}\text { No. of Cases } \\
\mathbf{( \% )}\end{array}$ & No. of Cases (\%) & $\begin{array}{c}\text { No. of Cases } \\
\mathbf{( \% )}\end{array}$ & $\begin{array}{c}\text { No. of Cases } \\
\mathbf{( \% )}\end{array}$ \\
\hline $\begin{array}{c}\text { Canada } \\
\text { United States }\end{array}$ & $2(66.7)$ & $0(0.0)$ & $1(33.3)$ & $3(100.0)$ \\
TOTAL & $36(94.7)$ & $1(2.6)$ & $1(2.6)$ & $38(100.0)$ \\
\hline
\end{tabular}

Table 4. Disposition on the Merits of Anglophone Caribbean IACHR Cases by State.

\begin{tabular}{ccccc}
\hline & $\begin{array}{c}\text { Responsible } \\
\text { on All Counts }\end{array}$ & $\begin{array}{c}\text { Responsible on } \\
\text { Some Counts, } \\
\text { Not Responsible } \\
\text { on Others }\end{array}$ & $\begin{array}{c}\text { Not } \\
\text { Responsible } \\
\text { on All Counts }\end{array}$ & Total \\
\hline State & $\begin{array}{c}\text { No. of Cases } \\
\mathbf{( \% )}\end{array}$ & $\begin{array}{c}\text { No. of Cases } \\
\mathbf{( \% )}\end{array}$ & $\begin{array}{c}\text { No. of Cases } \\
\mathbf{( \% )}\end{array}$ & $\begin{array}{c}\text { No. of Cases } \\
\mathbf{( \% )}\end{array}$ \\
\hline The Bahamas & $4(66.7)$ & $2(33.3)$ & $0(0.0)$ & $6(100.0)$ \\
Barbados & $2(100.0)$ & $0(0.0)$ & $0(0.0)$ & $2(100.0)$ \\
Belize & $1(100.0)$ & $0(0.0)$ & $0(0.0)$ & $1(100.0)$ \\
Grenada & $5(100.0)$ & $0(0.0)$ & $0(0.0)$ & $5(100.0)$ \\
Guyana & $2(100.0)$ & $0(0.0)$ & $0(0.0)$ & $2(100.0)$ \\
Jamaica & $11(57.9)$ & $1(5.3)$ & $7(36.8)$ & $19(100.0)$ \\
Trinidad and Tobago & $4(80.0)$ & $1(20.0)$ & $0(0.0)$ & $5(100.0)$ \\
TOTAL & $29(72.5)$ & $4(10.0)$ & $7(17.5)$ & $40(100.0)$ \\
\hline
\end{tabular}


Table 5. Disposition on the Merits of Hispanophone Central/South America and Caribbean IACHR Cases by State.

\begin{tabular}{ccccc}
\hline Responsible & $\begin{array}{c}\text { Responsible on } \\
\text { Some Counts, } \\
\text { on All Counts }\end{array}$ & $\begin{array}{c}\text { Not } \\
\text { on Others }\end{array}$ & $\begin{array}{c}\text { Tesponsible } \\
\text { on All Counts }\end{array}$ & \\
\hline State & $\begin{array}{c}\text { No. of Cases } \\
\mathbf{( \% )}\end{array}$ & No. of Cases (\%) & $\begin{array}{c}\text { No. of Cases } \\
\mathbf{( \% )}\end{array}$ & $\begin{array}{c}\text { No. of Cases } \\
\mathbf{( \% )}\end{array}$ \\
\hline Argentina & $55(82.1)$ & $6(9.0)$ & $6(9.0)$ & $67(100.0)$ \\
Bolivia & $17(94.4)$ & $1(5.6)$ & $0(0.0)$ & $18(100.0)$ \\
Chile & $37(92.5)$ & $1(2.5)$ & $2(5.0)$ & $40(100.0)$ \\
Colombia & $55(96.5)$ & $2(1.8)$ & $1(1.8)$ & $58(100.0)$ \\
Costa Rica & $4(66.7)$ & $0(0.0)$ & $2(33.3)$ & $6(100.0)$ \\
Cuba & $27(100.0)$ & $0(0.0)$ & $0(0.0)$ & $27(100.0)$ \\
Dominican Republic & $4(80.0)$ & $0(0.0)$ & $1(20.0)$ & $5(100.0)$ \\
Ecuador & $32(91.4)$ & $2(5.7)$ & $1(2.9)$ & $35(100.0)$ \\
El Salvador & $49(96.1)$ & $2(3.9)$ & $0(0.0)$ & $51(100.0)$ \\
Guatemala & $105(98.1)$ & $1(0.9)$ & $1(0.9)$ & $107(100.0)$ \\
Honduras & $19(90.5)$ & $1(4.8)$ & $1(4.8)$ & $21(100.0)$ \\
Mexico & $21(72.4)$ & $7(24.1)$ & $1(3.5)$ & $29(100.0)$ \\
Nicaragua & $34(100.0)$ & $0(0.0)$ & $0(0.0)$ & $34(100.0)$ \\
Panama & $7(87.5)$ & $1(12.5)$ & $0(0.0)$ & $8(100.0)$ \\
Paraguay & $22(91.7)$ & $2(8.3)$ & $0(0.0)$ & $24(100.0)$ \\
Peru & $160(99.4)$ & $0(0.0)$ & $1(0.6)$ & $161(100.0)$ \\
Uruguay & $11(84.6)$ & $1(7.7)$ & $1(7.7)$ & $13(100.0)$ \\
Venezuela & $23(82.1)$ & $5(17.9)$ & $0(0.0)$ & $28(100.0)$ \\
TOTAL & $682(93.2)$ & $32(4.4)$ & $18(2.5)$ & $732(100.0)$ \\
\hline
\end{tabular}

Table 6. Disposition on the Merits of Claims Made to the IACHR by Claim Type.

\begin{tabular}{|c|c|c|c|c|}
\hline & $\begin{array}{c}\text { Personal } \\
\text { Integrity Rights }\end{array}$ & $\begin{array}{c}\text { Civil and } \\
\text { Political Rights }\end{array}$ & $\begin{array}{l}\text { Rights to } \\
\text { Juridical } \\
\text { Personality }\end{array}$ & $\begin{array}{l}\text { Rights to } \\
\text { Equality }\end{array}$ \\
\hline Decision & $\begin{array}{c}\text { No. of Claims } \\
(\%)\end{array}$ & $\begin{array}{c}\text { No. of Claims } \\
(\%)\end{array}$ & $\begin{array}{c}\text { No. of Claims } \\
(\%)\end{array}$ & $\begin{array}{c}\text { No. of Claims } \\
(\%)\end{array}$ \\
\hline Responsible & $706(96.8)$ & $141(92.8)$ & $63(96.9)$ & $72(82.8)$ \\
\hline Not responsible & $23(3.2)$ & $11(7.2)$ & $2(3.1)$ & $15(17.2)$ \\
\hline \multirow[t]{2}{*}{ TOTAL } & $729(100.0)$ & $152(100.0)$ & $65(100.0)$ & $87(100.0)$ \\
\hline & Property Rights & Privacy Rights & $\begin{array}{c}\text { Judicial } \\
\text { Guarantees }\end{array}$ & $\begin{array}{c}\text { Freedom from } \\
\text { Ex Post Facto } \\
\text { Laws }\end{array}$ \\
\hline Decision & $\begin{array}{c}\text { No. of Claims } \\
(\%)\end{array}$ & $\begin{array}{l}\text { No. of Claims } \\
(\%)\end{array}$ & $\begin{array}{c}\text { No. of Claims } \\
(\%)\end{array}$ & $\begin{array}{c}\text { No. of Claims } \\
(\%)\end{array}$ \\
\hline Responsible & $48(85.7)$ & $60(87.0)$ & $640(95.8)$ & $30(90.9)$ \\
\hline Not responsible & $8(14.3)$ & $9(13.0)$ & $28(4.2)$ & $3(9.1)$ \\
\hline \multirow[t]{2}{*}{ TOTAL } & $56(100.0)$ & $69(100.0)$ & $668(100.0)$ & $33(100.0)$ \\
\hline & $\begin{array}{l}\text { Rights of the } \\
\text { Family }\end{array}$ & $\begin{array}{l}\text { Rights of the } \\
\text { Child }\end{array}$ & $\begin{array}{l}\text { Economic/Social/ } \\
\text { Cultural Rights }\end{array}$ & \\
\hline Decision & $\begin{array}{c}\text { No. of Claims } \\
(\%)\end{array}$ & $\begin{array}{c}\text { No. of Claims } \\
(\%)\end{array}$ & $\begin{array}{c}\text { No. of Claims } \\
(\%)\end{array}$ & \\
\hline Responsible & $33(91.7)$ & $68(95.8)$ & $9(69.2)$ & \\
\hline Not responsible & $3(8.3)$ & $3(4.2)$ & $4(30.8)$ & \\
\hline TOTAL & $36(100.0)$ & $71(100.0)$ & $13(100.0)$ & \\
\hline
\end{tabular}


Table 7. IACHR Decisions on Admissibility.

\begin{tabular}{cc}
\hline Decision & No. of Cases (\%) \\
\hline Admissible on all counts & $1628(68.0)$ \\
Admissible on some counts, & $509(21.3)$ \\
inadmissible on others & $258(10.8)$ \\
Inadmissible on all counts & $2395(100.0)$ \\
TOTAL &
\end{tabular}

Table 8. IACHR Inadmissibility Decisions by Reason(s) for Inadmissibility.

\begin{tabular}{cc}
\hline Reason & No. (\% of Inadmissible Cases) ${ }^{\mathbf{1}}$ \\
\hline Did not state facts that tend to establish a violation & $629(82.0)$ \\
Failure to exhaust domestic remedies & $118(15.4)$ \\
Failure to file timely claim & $41(5.3)$ \\
Duplicative claim & $10(1.3)$ \\
\hline
\end{tabular}

${ }^{1}$ Percentages total more than 100 due to multiple reasons being cited for the dismissal of some petitions.

Table 9. IACHR Decisions on Admissibility by Regime Type.

\begin{tabular}{ccc}
\hline & Left Party Government & Right Party Government \\
\hline Decision & No. of Cases (\%) & No. of Cases (\%) \\
\hline Admissible on all counts & $573(69.4)$ & $756(70.1)$ \\
Admissible on some counts, & $161(19.5)$ & $198(18.4)$ \\
inadmissible on others & $92(11.1)$ & $124(11.5)$ \\
Inadmissible on all counts & $826(100.0)$ & $1078(100.0)$ \\
TOTAL &
\end{tabular}

Table 10. North American IACHR Decisions on Admissibility by State.

\begin{tabular}{ccccc}
\hline & $\begin{array}{c}\text { Admissible } \\
\text { on All Counts }\end{array}$ & $\begin{array}{c}\text { Admissible on } \\
\text { Some Counts, } \\
\text { Inadmissible on } \\
\text { Others }\end{array}$ & $\begin{array}{c}\text { Inadmissible } \\
\text { on All Counts }\end{array}$ & Total \\
\hline State & No. of Cases (\%) & No. of Cases (\%) & No. of Cases (\%) & No. of Cases (\%) \\
\hline $\begin{array}{c}\text { Canada } \\
\text { United States }\end{array}$ & $4(44.4)$ & $2(22.2)$ & $3(33.3)$ & $9(100.0)$ \\
TOTAL & $60(66.7)$ & $19(21.1)$ & $11(12.2)$ & $90(100.0)$ \\
\hline
\end{tabular}

Table 11. Anglophone Caribbean IACHR Decisions on Admissibility by State.

\begin{tabular}{ccccc}
\hline & $\begin{array}{c}\text { Admissible } \\
\text { on All Counts }\end{array}$ & $\begin{array}{c}\text { Admissible on } \\
\text { Some Counts, } \\
\text { Inadmissible on } \\
\text { Others }\end{array}$ & $\begin{array}{c}\text { Inadmissible } \\
\text { on All Counts }\end{array}$ & Total \\
\hline State & No. of Cases (\%) & No. of Cases (\%) & No. of Cases (\%) & $\begin{array}{c}\text { No. of Cases } \\
\text { (\%) }\end{array}$ \\
\hline The Bahamas & $8(88.9)$ & $0(0.0)$ & $1(11.1)$ & $9(100.0)$ \\
Barbados & $2(100.0)$ & $0(0.0)$ & $0(0.0)$ & $2(100.0)$ \\
Belize & $1(50.0)$ & $1(50.0)$ & $0(0.0)$ & $2(100.0)$ \\
Grenada & $5(100.0)$ & $0(0.0)$ & $0(0.0)$ & $5(100.0)$ \\
Guyana & $2(66.7)$ & $1(33.3)$ & $0(0.0)$ & $3(100.0)$ \\
Jamaica & $36(87.8)$ & $2(4.9)$ & $0(0.0)$ & $41(100.0)$ \\
St. Lucia & $0(0.0)$ & $1(100.0)$ & $0(0.0)$ & $1(100.0)$ \\
Trinidad and Tobago & $20(95.2)$ & $1(4.8)$ & $4(4.8)$ & $21(100.0)$ \\
TOTAL & $74(88.1)$ & $6(7.1)$ & & $84(100.0)$ \\
\hline
\end{tabular}


Table 12. Hispanophone Central/South America and Caribbean IACHR Decisions on Admissibility by State.

\begin{tabular}{ccccc}
\hline Admissible & $\begin{array}{c}\text { Admissible on } \\
\text { Some Counts, } \\
\text { on All Counts } \\
\text { Inadmissible on } \\
\text { Others }\end{array}$ & $\begin{array}{c}\text { Inadmissible } \\
\text { on All Counts }\end{array}$ & Total \\
State & $\begin{array}{c}\text { No. of Cases } \\
\mathbf{( \% )}\end{array}$ & $\begin{array}{c}\text { No. of Cases } \\
\mathbf{( \% )}\end{array}$ & $\begin{array}{c}\text { No. of Cases } \\
\mathbf{( \% )}\end{array}$ & $\begin{array}{c}\text { No. of Cases } \\
\mathbf{( \% )}\end{array}$ \\
\hline Argentina & $125(59.5)$ & $55(26.2)$ & $30(14.3)$ & $210(100.0)$ \\
Bolivia & $37(84.1)$ & $4(9.1)$ & $3(6.8)$ & $44(100.0)$ \\
Chile & $128(83.1)$ & $15(9.7)$ & $11(7.1)$ & $154(100.0)$ \\
Colombia & $195(60.4)$ & $120(37.2)$ & $8(2.5)$ & $323(100.0)$ \\
Costa Rica & $17(45.9)$ & $9(24.3)$ & $11(29.7)$ & $37(100.0)$ \\
Cuba & $27(100.0)$ & $0(0.0)$ & $0(0.0)$ & $27(100.0)$ \\
Dominican Republic & $8(66.7)$ & $3(25.0)$ & $1(8.3)$ & $12(100.0)$ \\
Ecuador & $107(64.1)$ & $45(26.9)$ & $15(9.0)$ & $167(100.0)$ \\
El Salvador & $66(89.2)$ & $6(8.1)$ & $2(2.7)$ & $74(100.0)$ \\
Guatemala & $135(80.4)$ & $26(15.5)$ & $7(4.2)$ & $168(100.0)$ \\
Honduras & $46(66.7)$ & $9(13.0)$ & $14(20.3)$ & $69(100.0)$ \\
Mexico & $96(58.2)$ & $46(27.9)$ & $23(13.9$ & $165(100.0)$ \\
Nicaragua & $38(80.9)$ & $5(10.6)$ & $4(8.5)$ & $47(100.0)$ \\
Panama & $18(54.5)$ & $8(24.2)$ & $7(21.2)$ & $33(100.0)$ \\
Paraguay & $35(62.5)$ & $13(23.2)$ & $8(14.3)$ & $56(100.0)$ \\
Peru & $235(66.0)$ & $58(16.3)$ & $63(17.7)$ & $356(100.0)$ \\
Uruguay & $16(66.7)$ & $3(12.5)$ & $5(20.8)$ & $24(100.0)$ \\
Venezuela & $35(53.0)$ & $21(31.8)$ & $10(15.2)$ & $66(100.0)$ \\
TOTAL & $1364(67.1)$ & $446(21.9)$ & $222(10.9)$ & $2032(100.0)$ \\
\hline
\end{tabular}

Table 13. IACHR Decisions on Admissibility by Claim Type.

\begin{tabular}{|c|c|c|c|c|}
\hline & $\begin{array}{c}\text { Personal } \\
\text { Integrity Rights }\end{array}$ & $\begin{array}{c}\text { Civil and } \\
\text { Political Rights }\end{array}$ & $\begin{array}{l}\text { Rights to } \\
\text { Juridical } \\
\text { Personality }\end{array}$ & $\begin{array}{l}\text { Rights to } \\
\text { Equality }\end{array}$ \\
\hline Decision & $\begin{array}{c}\text { No. of Claims } \\
(\%)\end{array}$ & $\begin{array}{c}\text { No. of Claims } \\
(\%)\end{array}$ & $\begin{array}{c}\text { No. of Claims } \\
(\%)\end{array}$ & $\begin{array}{c}\text { No. of Claims } \\
(\%)\end{array}$ \\
\hline Admissible & $1624(86.6)$ & $513(78.8)$ & $182(84.3)$ & $362(55.8)$ \\
\hline Inadmissible & $252(13.4)$ & $138(21.2)$ & $34(15.7)$ & $287(44.2)$ \\
\hline \multirow[t]{2}{*}{ TOTAL } & $1876(100.0)$ & $651(100.0)$ & $216(100.0)$ & $649(100.0)$ \\
\hline & Property Rights & Privacy Rights & $\begin{array}{l}\text { Judicial } \\
\text { Guarantees }\end{array}$ & $\begin{array}{c}\text { Freedom from } \\
\text { Ex Post Facto } \\
\text { Laws }\end{array}$ \\
\hline Decision & $\begin{array}{c}\text { No. of Claims } \\
(\%)\end{array}$ & $\begin{array}{l}\text { No. of Claims } \\
(\%)\end{array}$ & $\begin{array}{c}\text { No. of Claims } \\
(\%)\end{array}$ & $\begin{array}{c}\text { No. of Claims } \\
(\%)\end{array}$ \\
\hline Admissible & $203(68.4)$ & 275 (59.3) & $1875(87.3)$ & 109 (63.7) \\
\hline Inadmissible & $94(31.6)$ & 189 (40.7) & $273(12.7)$ & $62(36.3)$ \\
\hline \multirow[t]{2}{*}{ TOTAL } & $297(100.0)$ & $464(100.0)$ & $2148(100.0)$ & $171(100.0)$ \\
\hline & $\begin{array}{l}\text { Rights of the } \\
\text { Family }\end{array}$ & $\begin{array}{l}\text { Rights of the } \\
\text { Child }\end{array}$ & $\begin{array}{l}\text { Economic/Social/ } \\
\text { Cultural Rights }\end{array}$ & \\
\hline Decision & $\begin{array}{c}\text { No. of Claims } \\
(\%)\end{array}$ & $\begin{array}{c}\text { No. of Claims } \\
(\%)\end{array}$ & $\begin{array}{l}\text { No. of Claims } \\
(\%)\end{array}$ & \\
\hline Admissible & $146(69.5)$ & $277(91.4)$ & $171(75.7)$ & \\
\hline Inadmissible & $64(30.5)$ & $26(8.6)$ & $55(24.3)$ & \\
\hline TOTAL & $210(100.0)$ & $303(100.0)$ & $226(100.0)$ & \\
\hline
\end{tabular}


Table 14. Logit Model Predicting IACHR Decisions on the Merits.

\begin{tabular}{|c|c|}
\hline Variable & Coefficient \\
\hline \multicolumn{2}{|l|}{ State variables } \\
\hline Polity score & $-0.107 *(-2.04)$ \\
\hline CIRI Human Rights Index score & $-2.053 *(-2.38)$ \\
\hline Adjusted per capita GDP & $-0.000 *(-2.44)$ \\
\hline Recognition of IACtHR jurisdiction & $1.001(1.77)$ \\
\hline Left party government & $-0.453(-0.81)$ \\
\hline Right party government & $-0.487(-0.90)$ \\
\hline North America & $9.001 * *(3.33)$ \\
\hline Anglophone Caribbean & $-0.546(-0.47)$ \\
\hline Hispanophone Central/South America and Caribbean & $-0.416(-0.43)$ \\
\hline \multicolumn{2}{|l|}{ Claim variables } \\
\hline Personal integrity rights & $1.988^{* * *}(4.07)$ \\
\hline Civil and political rights & $1.644^{* *}(2.91)$ \\
\hline Rights to juridical personality & $1.571(0.87)$ \\
\hline Rights to equality & $-0.208(-0.42)$ \\
\hline Property rights & $-0.158(-0.26)$ \\
\hline Privacy rights & $-0.628(-0.98)$ \\
\hline Judicial guarantees & $2.828^{* * *}(6.49)$ \\
\hline Freedom from ex post facto laws & $-0.077(-0.08)$ \\
\hline Rights of the family & $1.053(1.04)$ \\
\hline Rights of the child & $0.408(0.42)$ \\
\hline Economic, social, and cultural rights & $-2.640 * *(-2.66)$ \\
\hline Log likelihood & $-119.044^{* * *}$ \\
\hline Pseudo $\mathrm{R}^{2}$ & 0.382 \\
\hline $\mathrm{N}$ & 729 \\
\hline
\end{tabular}

Table 15. Logit Model Predicting IACHR Decisions on Admissibility.

\begin{tabular}{|c|c|}
\hline Variable & Coefficient \\
\hline \multicolumn{2}{|l|}{ State variables } \\
\hline Polity score & $-0.069 * *(-3.43)$ \\
\hline CIRI Human Rights Index score & $-0.447(-1.66)$ \\
\hline Adjusted per capita GDP & $0.000(0.07)$ \\
\hline Recognition of IACtHR jurisdiction & $-0.613 *(-2.22)$ \\
\hline Left party government & $0.354 *(2.04)$ \\
\hline Right party government & $0.030(0.18)$ \\
\hline North America & $0.230(0.28)$ \\
\hline Anglophone Caribbean & $0.674(1.17)$ \\
\hline Hispanophone Central/South America and Caribbean & $0.607 *(2.40)$ \\
\hline \multicolumn{2}{|l|}{ Claim variables } \\
\hline Personal integrity rights & $1.608^{* * *}(11.10)$ \\
\hline Civil and political rights & $0.858^{* * *}(5.56)$ \\
\hline Rights to juridical personality & $0.294(0.91)$ \\
\hline Rights to equality & $-1.058^{* * *}(-7.31)$ \\
\hline Property rights & $-0.655^{* * *}(-3.68)$ \\
\hline Privacy rights & $-0.835^{* * *}(-4.92)$ \\
\hline Judicial guarantees & $3.037^{* * *}(21.79)$ \\
\hline Freedom from ex post facto laws & $-0.541 *(-2.51)$ \\
\hline Rights of the family & $-0.043(-0.17)$ \\
\hline Rights of the child & $0.766^{* *}(2.82)$ \\
\hline Economic, social, and cultural rights & $0.510 *(2.22)$ \\
\hline Log likelihood & $-918.364^{* * *}$ \\
\hline Pseudo $\mathrm{R}^{2}$ & 0.406 \\
\hline $\mathrm{N}$ & 2595 \\
\hline
\end{tabular}


Examining the results more closely, the results of the updated regression analysis of merits decisions are largely consistent with the results of previous analysis of merits decisions (see Table 14). All of the variables measuring states' levels of democratization, human rights protection, and economic development that were statistically significant in the previous analysis remained significant in the updated analysis. In particular, as expected, states with higher Polity scores, higher scores on the CIRI Human Rights Index, and higher adjusted per capita GDPs were significantly less likely to be found responsible for human rights violations. Furthermore, as was the case in the previous analysis, there was no evidence of political bias at the merits phase. As indicated in Table 2, the overall disposition of cases involving leftist and rightist governments was nearly identical and neither the "left party government" nor the "right party government" variable was statistically significant in the regression analysis.

With regard to the question of political bias at the merits phase, it is also noteworthy that the two states that were by far the most frequently condemned for human rights violations were Guatemala and Peru. This is inconsistent with critics' narrative of a system targeting left-wing regimes because these violations were overwhelmingly perpetrated by right-wing regimes. These violations primarily involved abuses committed by state and private paramilitary forces in the context of civil conflicts. In Guatemala these largely occurred under the series of right-wing military regimes that governed the country from 1970 to 1986 and the series of right-wing civilian regimes that have held power almost continuously since whereas in Peru they largely occurred under the right-wing regime of Alberto Fujimori, which governed the country from 1990 to 2000. In a similar vein, the very large number of decisions condemning Colombia for human rights violations is also inconsistent with critical narratives insofar as the Colombian regimes that have been continually condemned for abuses in the context of the country's ongoing civil conflict have all been centrist and right-wing regimes, not left-wing regimes.

Additionally, contrary to narratives portraying the Inter-American system as an American-dominated system, North American states were (as in the previous analysis) significantly more likely to be found responsible for human rights violations. This apparent bias against North American states could better be described as an apparent bias against the United States in particular since 38 of the 41 North American cases were cases involving the United States (see Table 3). This can be attributed in part to the IACHR's longstanding opposition to the death penalty (see Inter-American Commission on Human Rights 2011) insofar as 25 of the 38 cases brought against the United States involved successful claims by death row inmates that their impending executions would violate the Declaration. However, the United States fared almost as poorly in non-death penalty cases, with 11 of these 13 cases ending in decisions finding the United States responsible for all of the human rights violations that it was accused of. These non-death penalty cases have seen the IACHR recently condemn the United States, for example, for its failure to compensate all Japanese Americans interned during World War II, its treatment of alleged unlawful enemy combatants at the Guantánamo Bay detention camp, and its violations of international humanitarian law during its 1989 invasion of Panama. ${ }^{11}$ The fact that the United States was found responsible for all of the human rights violations that it was accused of in $85 \%$ of these non-death penalty cases is noteworthy because other states with similarly good performance on democratization and human rights indices such as Polity and CIRI fared far better. For example, only $58 \%$ of the cases brought against other states scoring a perfect 10 on the Polity index resulted in a decision finding the state in question responsible for all of the human rights violations that it was accused of. However, there may be reasons other than anti-American bias for this result. One may be the strength of human rights protection and the rule of law in the American domestic legal system, which may keep all but relatively strong claims of human rights violations by the United States from passing

11 Isamu Carlos Shibayama et al., Case 12.545, Inter-Am. Comm'n H.R., Report No. 26/20, OEA/Ser.L/V/II, Doc. 36 (2020); Djamel Ameziane, Case 12.865, Inter-Am. Comm'n H.R., Report No. 29/20, OEA/Ser.L/V/II, Doc. 39 (2020); José Isabel Salas Galindo et al., Case 10.573, Inter-Am. Comm'n H.R., Report No. 121/18, OEA/Ser.L/V/II.169, Doc. 138 (2018). 
the pre-admissibility and admissibility phases. Nonetheless, at the very least it can be said that there is no merit to assertions that the OAS's reliance on American funding has led the Inter-American system to turn a "blind eye to human rights violations in the United States" (Rivera Juaristi 2013, p. 19).

The results also indicate that there is no merit to claims that the states of the Anglophone Caribbean have been the victims of disparate treatment. Despite the fact that these states, like the United States, have been the targets of a large amount of death penalty litigation, on balance they were not (as was also the case in the previous analysis) significantly more likely to be found responsible for human rights violations. Indeed, as indicated by the descriptive statistics in Table 4, only $73 \%$ of the cases brought against Anglophone Caribbean states resulted in a decision finding the state in question responsible for all of the human rights violations that it was accused of. This is substantially lower than the $93 \%$ of cases involving North American and Spanish-speaking states that resulted in such decisions (see Tables 4 and 5). Furthermore, the sign of the "Anglophone Caribbean" variable was negative in the logit model (indicating that these states were less likely to be found responsible for human rights violations even when controlling for their generally high levels of democratization and human rights protection).

However, the results do provide some support for accusations of a "hierarchization" of rights. In particular, consistent with complaints by critics of the Inter-American system that the system has placed excessive emphasis on freedom of thought and expression and other negative rights and liberties, cases involving claims of violations of civil and political rights were significantly more likely to result in findings of responsibility for human rights violations (as were cases involving claims of violations of personal integrity rights and judicial guarantees). This is largely attributable to the IACHR's expansive interpretation of the right to freedom of thought and expression, one that has regularly led the IACHR to condemn states with otherwise good human rights records for violations of the Convention or Declaration (see, e.g., Grossman 2001, 2012; Mason 2012). Notable examples include the IACHR condemning Chile's censorship of the film The Last Temptation of Christ on religious grounds in Juan Pablo Olmedo Bustos et al., condemning Costa Rica's law requiring journalists charged with criminal defamation to prove the truth of what they publish in Mauricio Herrera Ulloa, and holding in Eduardo Kimel that the right to freedom of thought and expression trumps the right of public officials to honor and dignity. ${ }^{12}$

Additionally, consistent with critical narratives was the fact that claims of violations of economic, social, and cultural rights were significantly less likely to result in findings of responsibility for human rights violations. Although the sample size of 13 cases in which such claims were made was small, the fact that $31 \%$ of them resulted in the state in question being found not responsible for violations of economic, social, and cultural rights made this the least successful claim type at the merits phase (see Table 6). However, it should be noted that both the attentiveness and receptiveness of the IACHR to claims of violations of economic, social, and cultural rights have increased significantly in recent years. Decisions such as Jorge Odir Miranda Cortez et al., in which the IACHR interpreted states' economic, social, and cultural rights obligations primarily as a negative "obligation not to adopt regressive measures", ${ }^{13}$ had led many observers to be skeptical of the potential future development of those obligations. This was especially the case given that more robust economic, social, and cultural rights obligations may be unmanageable for the developing states that make up most of the OAS's membership (see Ruiz-Chiriboga 2013b). Nonetheless, in the last three years the IACHR has delivered more decisions condemning states for violations of economic, social, and cultural rights than in its entire previous history. These have included, for example, its decision in Employees of the Fireworks Industry in Santo Antônio de Jesus and their Families condemning Brazil's failure to inspect a factory

12 Juan Pablo Olmedo Bustos et al., Case 11.803, Inter-Am. Comm'n H.R., Report No. 31/98, OEA/Ser.L/V/II.102, Doc. 6 Rev. 1 (1999); Mauricio Herrera Ulloa, Case 12.367, Inter-Am. Comm'n H.R., Report No. 64/02, OEA/Ser.L/V/II.118, Doc. 5 Rev. 2 (2002); Eduardo Kimel, Case 12.450, Inter-Am. Comm'n H.R., Report No. 111/06, OEA/Ser.L/V/II.130, Doc. 22 Rev. 1 (2007).

13 Jorge Odir Miranda Cortez et al., Case 12.249, Inter-Am. Comm'n H.R., Report No. 27/09, OEA/Ser.L/V/II, Doc. 51 Corr. 1 (2009). 
in which hazardous activities and child labor were occurring, its decision in Luis Eduardo Guachala Chimbo and Family condemning Ecuador's failure to determine the whereabouts of a missing patient who had been institutionalized in a public psychiatric hospital, and its decision in T.B. and S.H. condemning the unavailability of adequate HIV prevention, testing, and treatment services in Jamaica. ${ }^{14}$ Opening the door to this revolution in the InterAmerican system's economic, social, and cultural rights jurisprudence was the IACtHR's landmark 2017 decision in Lagos del Campo v. Peru, in which the court held that the firing of a labor union leader who gave an interview denouncing his employer's labor practices violated his right to job security. ${ }^{15}$ In this decision, the first in which the IACtHR found a state in violation of Article 26, the court placed economic, social, and cultural rights on the same plane as other Convention rights, declaring that "civil and political rights and economic, social, and cultural rights ... should all be understood integrally as human rights, without any specific hierarchy". ${ }^{16}$

Finally, although previous analysis of merits decisions found that claims of violations of rights to equality were significantly less likely to result in findings of responsibility for human rights violations, this was no longer the case in the updated analysis including cases decided between 2016 and 2020. This discrepancy can be attributed to a recent increase in the attentiveness and receptiveness of the IACHR to such claims. For example, between 2016 and 2020 there were 25 cases decided in which the IACHR found states responsible for violations of rights to equality, which is more than a third of the total number of such cases decided in the IACHR's entire history (72). Some of these recent decisions condemning violations of rights to equality have included, for example, the IACHR's decision in Undocumented Workers condemning the denial of labor rights to undocumented immigrants in the United States, its decision in Vicky Hernández and Family condemning Honduras's failure to exercise due diligence in investigating the murder of a trans woman and rights activist, and its decision in Gareth Henry and Simone Carline Edwards condemning Jamaica's criminalization of same-sex relationships. ${ }^{17}$

Turning from the merits to the admissibility phase, the data indicate that failure to satisfy Article 47(b)'s requirement that petitions "state facts that tend to establish a violation" ${ }^{18}$ was the reason for the IACHR's decision in the vast majority of cases in which it declared a petition either wholly or partially inadmissible (see Table 8 ). In $82 \%$ of these cases, the failure to make a prima facie case was either the sole reason cited for inadmissibility or one of the reasons cited for inadmissibility (the IACHR sometimes cited multiple reasons for declaring either an entire petition or some of the claims made in a petition inadmissible). On the other hand, declarations of inadmissibility for procedural reasons were far less common. Only $15 \%$ of the petitions declared wholly or partially inadmissible were declared inadmissible for failure to exhaust domestic remedies as required by Article 46(1)(a). This is significant insofar as the Inter-American system's domestic remedies rule (as well as that of the European system) is more rigid than the African system's domestic remedies rule, which excuses non-compliance in a broader range of circumstances (see Udombana 2003). Nonetheless, Article 46(2), which excuses non-compliance in cases in which the domestic legal system of the state concerned "does not afford due process of law for protection of the right or rights that have allegedly been violated", has "denied access" to the petitioner, or has engaged in "unwarranted delay", ${ }^{19}$ provides for some flexibility. Thus, despite being somewhat less permissive than the African system's domestic remedies rule, the

14 Employees of the Fireworks Industry in Santo Antônio de Jesus and their Families, Case 12.428, Inter-Am. Comm'n H.R., Report No. 25/18, OEA/Ser.L/V/II.167, Doc. 29 (2018); Luis Eduardo Guachala Chimbo and Family, Case 12.786, Inter-Am. Comm'n H.R., Report No. 111/18, OEA/Ser.L/V/II.169, Doc. 128 (2018); T.B. and S.H., Case 13.095, Inter-Am. Comm'n H.R., Report No. 401/20, OEA/Ser.L/V/II, Doc. 419 (2020).

15 Lagos del Campo v. Peru, Preliminary Objections, Merits, Reparations, and Costs, Judgment, Inter-Am. Ct. H.R. (ser. C) No. 340 (31 August 2017).

16 Id. II 141.

17 Undocumented Workers, Case 12.834, Inter-Am. Comm'n H.R., Report No. 50/16, OEA/Ser.L/V/II.159 (2016); Vicky Hernández and Family, Case 13.051, Inter-Am. Comm'n H.R., Report No. 157/18, OEA/Ser.L/V/II.170, Doc. 179 (2018); Gareth Henry and Simone Carline Edwards, Case 13.637, Inter-Am. Comm'n H.R., Report No. 400/20, OEA/Ser.L/V/II, Doc. 418 (2020).

18 American Convention on Human Rights (22 November 1969), Art. 47(b). OAS Treaty Series No. 36.

19 Id. Art. 46(2). 
Inter-American system's domestic remedies rule has not, considering the total number of petitions reaching the admissibility phase, been an overly onerous barrier to petitioners.

Other procedural reasons for dismissal were invoked even less frequently. Only $5 \%$ of the petitions declared wholly or partially inadmissible were declared inadmissible for failure to adhere to Article 46(1)(b)'s requirement that the petition be filed within six months of receiving notice of the final domestic decision (or within six months of the alleged violation if there was no domestic decision). Once again, despite the Inter-American system providing petitioners with less flexibility than the African system by imposing a strict deadline (rather than considering on a case-by-case basis whether the petition was filed in a reasonable amount of time), relatively few cases have been dismissed for failure to comply with the more rigid rule. Finally, only $1 \%$ of the petitions declared wholly or partially inadmissible were declared inadmissible for being duplicative petitions in violation of Article 47(d), which prohibits the consideration of petitions "substantially the same as one previously studied by the Commission or by another international organization". ${ }^{20}$

Further insight into the dynamics of the admissibility phase and how they differ from those of the merits phase is provided by the results of the regression analysis of admissibility decisions. The results indicate that, compared to merits decisions, differences in the characteristics of states were less important and differences in the types of claims being made more important. In particular, whereas all three of the variables measuring states' levels of democratization, human rights protection, and economic development were significant predictors of merits decisions, only one (Polity score) was a significant predictor of admissibility decisions. As expected and consistent with the analysis of merits decisions, petitions against states with higher Polity scores were significantly less likely to be declared admissible. In contrast, all but two of the claim type variables (rights to juridical personality and rights of the family) were significant predictors of admissibility decisions. Furthermore, the apparent anti-American bias seen at the merits phase was not seen at the admissibility phase, indicating that this apparent bias may be an artifact of the types of cases brought against the United States that reach the merits phase. Not only did the regression analysis not find that petitions filed against North American states were significantly more likely to be declared admissible, the percentage of such petitions declared wholly admissible was actually the lowest of the three regions (see Tables 10-12). That state-level characteristics were less determinative of admissibility decisions than merits decisions is not surprising given the lower threshold for passing the admissibility phase, where petitioners need only make a prima facie case.

Nonetheless, three state-level characteristics that were not significant predictors of merits decisions were significant predictors of admissibility decisions. In particular, petitions against states recognizing the IACtHR's contentious case jurisdiction were significantly less likely to be declared admissible. This indicates that recognition of the IACtHR's jurisdiction may positively affect state behavior in ways not captured by democratization and human rights indices such as Polity and CIRI. Additionally, petitions against states with left-wing governments were significantly more likely to be declared admissible. Although, as indicated by the descriptive statistics in Table 9, the overall percentages of petitions declared wholly admissible, partially admissible, and wholly inadmissible were nearly identical for states with left-wing governments and states with right-wing governments, the regression analysis indicates that the percentage of petitions against states with leftwing governments that were declared admissible was higher than would be expected given the other characteristics of the states in question and the types of claims being made. That petitions against states with left-wing governments were more likely to be declared admissible even when controlling for other relevant factors is consistent with the claims of political bias made by the ALBA member states and something that merits further analysis.

Finally, petitions against Spanish-speaking states were also significantly more likely to be declared admissible. This may be the result of the human rights issues that have 
been endemic to Latin America not being fully captured by Polity and CIRI Human Rights Index scores. It may also be the result of greater utilization of the Inter-American system by citizens of Latin American states. For example, the per capita number of petitions from Spanish-speaking states reaching the admissibility phase (approximately seven per million population) is more than 20 times the per capita number of petitions from North American states reaching the admissibility phase (approximately 0.3 per million population). This is attributable not merely to the higher level of human rights abuse in Latin America and to the fact that most Latin American states (but no North American states and only one Anglophone Caribbean state) recognize the jurisdiction of the IACtHR but also to the significantly greater public awareness of the Inter-American system and its work that exists in Latin America (see Cavallaro and Brewer 2008). Although this greater visibility may contribute to the filing of some frivolous petitions that would not otherwise be filed, it appears also to have contributed to the filing of a still greater number of meritorious petitions that would not otherwise be filed.

Ultimately, however, it was the claim type variables that exerted the greatest effect on admissibility decisions. The results of the regression analysis of admissibility decisions largely aligned with those of the regression analysis of merits decisions in this regard. Claims of violations of personal integrity rights, civil and political rights, and judicial guarantees, which were significantly more likely to result in findings of state responsibility for human rights violations, were also significantly more likely to be declared admissible. Nonetheless, there were some notable differences. For example, claims of violations of rights to equality were significantly less likely to be declared admissible, a finding that superficially fits critical narratives of the Inter-American system as a system that has deemphasized social justice. Indeed, as indicated by the descriptive statistics in Table 13, only $56 \%$ of such claims were declared admissible, the lowest admission rate of any of the claim types. However, just as was the case with claims of violations of rights to equality rejected at the merits phase, overwhelmingly claims of violations of rights to equality rejected at the admissibility phase did not involve claims of discrimination on traditionally suspect grounds such as race and gender. The IACHR was invariably receptive to such claims at both the merits and the admissibility phase. Instead, they tended to involve vague and unsubstantiated claims of disparate treatment.

Indeed, the IACHR has recently taken several steps to increase its scrutiny of the treatment of other marginalized groups in the Americas. In particular, it has taken steps to give special attention to cases involving discrimination on the basis of sexual orientation and gender identity. Not only did it create a special Unit on the Rights of Lesbian, Gay, Trans, Bisexual, and Intersex Persons in 2011, it has invoked Article 29(2) of the IACHR's Rules of Procedure to expedite the review of all cases involving discrimination on the basis of sexual orientation and gender identity (see Paul 2016). Article 29(2) permits a petition to be processed out of the order in which it was received in cases in which a decision "could have the effect of repairing serious structural situations that would have an impact in the enjoyment of human rights" or "could promote changes in legislation or state practices and avoid the reception of multiple petitions on the same matter". ${ }^{21}$ The impact of these initiatives has been particularly evident in the admissibility phase, with 13 petitions claiming discrimination on the basis of sexual orientation or gender identity having been declared admissible since the creation of the Unit on the Rights of Lesbian, Gay, Trans, Bisexual, and Intersex Persons.

Another finding relevant to assessing the veracity of the narrative that has been promoted by critics of the Inter-American system, specifically the accusation that it is a neoliberal institution that has favored economic elites, is fact that claims of violations of property rights were significantly less likely to be declared admissible. Such accusations are further belied by the fact that claims of violations of economic, social, and cultural rights were significantly more likely to declared admissible. Whereas claims of violations 
of economic, social, and cultural rights were significantly more likely to be rejected at the merits phase, the opposite was true at the admissibility phase. This reflects the dramatic increase in the number of petitions invoking economic, social, and cultural rights that have been declared admissible in recent years, something that promises to reverse the neglect of economic, social, and cultural rights that has heretofore characterized the InterAmerican system. Thus, whereas former IACHR President James Cavallaro concluded in 2004 that "the effectiveness of the Inter-American system in protecting economic, social, and cultural rights has been practically nil" (Cavallaro and Schaffer 2004, p. 226), the OAS has in recent years taken several steps to change this. Not only did the IACHR establish a special Unit on Economic, Social, and Cultural Rights in 2012 (upgraded in 2014 to a Special Rapporteurship on Economic, Social, Cultural, and Environmental Rights), the first OAS working group to examine state reports on the fulfillment of economic, social, and cultural rights met in 2015. The impact of these initiatives has also been most evident in the admissibility phase, as nearly $75 \%$ of the petitions invoking economic, social, and cultural rights that have ever been admitted in the Inter-American system were admitted in the last three years.

Yet another finding that tends to contradict critiques of the Inter-American system as excessively focused on negative rights and liberties is the fact that claims of violations of rights to privacy were significantly less likely to be declared admissible. Indeed, only $59 \%$ of such claims were declared admissible, the second lowest admission rate of any of the claim types. Although the IACHR has in recent years extended its privacy rights jurisprudence into the area of abortion rights, condemning in 2018 El Salvador's conviction of aggravated homicide of a woman who suffered a miscarriage in Manuela and Family ${ }^{22}$ and declaring several other abortion cases admissible, this has not marked a more general shift in the IACHR's approach to privacy cases. Finally, although there was no particular reason to expect them to be significantly more or less likely to be declared admissible, claims of violations of the prohibition of ex post facto laws were significantly less likely to be declared admissible while claims of violations of the rights of the child were significantly more likely to be declared admissible.

\section{Conclusions}

This analysis has extended previous research analyzing the dynamics of the merits phase to the admissibility phase. In so doing, it has further demonstrated that most of the claims of bias that have been made against the Inter-American system are either wholly baseless or outdated. Contrary to claims that the system is a "platform for US imperialism" (Picq 2012), to the extent that there has been bias in cases involving the United States, it has been arguably been bias against the United States. Additionally, while the system could have been accused of neglecting economic, social, and cultural rights and rights to equality in the past, this is no longer the case due to recent initiatives. Furthermore, while the system has indeed placed special emphasis on freedom of thought and expression, most would likely consider this a virtue rather than a flaw in the system. These findings are significant insofar as they provide further reason to be skeptical of calls to radically change the system such as those that triggered the 2011-13 "strengthening" process. However, the analysis did produce corroborating evidence for one of the central claims of the system's critics: bias against leftist governments. All else being equal, claims against states with leftist governments were more likely to be declared admissible. This contrasts with previous research analyzing the merits phase, which found no evidence of political bias, and indicates that attitudinal factors may play a greater role in the admissibility phase. This is a finding that calls for more in depth, qualitative future research given the importance of maintaining confidence in the impartiality of a system that has played an increasingly important role in safeguarding human rights in the region. 
Funding: This research received no external funding.

Institutional Review Board Statement: Not applicable.

Informed Consent Statement: Not applicable.

Data Availability Statement: Data available from author on request.

Conflicts of Interest: The author declares no conflict of interest.

\section{References}

Agencia EFE. 2016. Correa Calls for New Inter-American Human Rights System. Available online: https:/ /www.efe.com/efe/english/ life/correa-calls-for-new-inter-american-human-rights-system/50000263-3064355 (accessed on 5 June 2021).

ANDES. 2015. Rafael Correa: "Let's Talk about Human Rights, in Ecuador There Is No Torture or Extrajudicial Executions". Available online: https: / www.pressenza.com/2015/04/rafael-correa-lets-talk-about-human-rights-in-ecuador-there-is-no-torture-orextrajudicial-executions / (accessed on 5 June 2021).

Arriagada, Milenko. 2015. The New Legitimacy Challenges of Adjudication at the Inter-American Human Rights System in the Context of Latin American Democracies. SJD dissertation, American University, Washington, DC, USA.

Biron, Carey. 2013. Controversial Inter-American Reforms Process to Continue. Available online: http://www.ipsnews.net/2013/03/ controversial-inter-american-reforms-process-to-continue/ (accessed on 5 June 2021).

Boyle, Elizabeth, and Melissa Thompson. 2001. National Politics and Resort to the European Commission on Human Rights. Law E Society Review 35: 321-44.

Carozza, Paolo. 2015. The Anglo-Latin Divide and the Future of the Inter-American System of Human Rights. Notre Dame Journal of International \& Comparative Law 5: 153-70.

Carrillo, Nicolás. 2018. Gender Identity and Equality and Non-Discrimination of Same-Sex Couples. American Journal of International Law 112: 479-85. [CrossRef]

Cavallaro, James, and Emily Schaffer. 2004. Less as More: Rethinking Supranational Litigation of Economic, Social, and Cultural Rights in the Americas. Hastings Law Journal 56: 217-82.

Cavallaro, James, and Stephanie Brewer. 2008. Reevaluating Regional Human Rights Litigation in the 21st Century: The Case of the Inter-American Court. American Journal of International Law 102: 768-827. [CrossRef]

Cole, Rowland. 2010. The African Court on Human and Peoples' Rights: Will Political Stereotypes Form an Obstacle to the Enforcement of Its Decisions? Comparative E International Law Journal of Southern Africa 43: 23-45.

Cole, Wade. 2006. When All Else Fails: International Adjudication of Human Rights Abuse Claims, 1976-1999. Social Forces 84: 1909-35. [CrossRef]

Cole, Wade. 2011. Individuals vs. States: The Correlates of Human Rights Committee Rulings, 1979-2007. Social Science Research 40: 985-1000. [CrossRef]

Concepción, Natasha. 2001. The Legal Implications of Trinidad \& Tobago's Withdrawal from the American Convention on Human Rights. American University International Law Review 16: 847-90.

Contesse, Jorge. 2018. The Inter-American Court of Human Rights' Advisory Opinion on Gender Identity and Same-Sex Marriage. ASIL Insights 22. Available online: https:/ / www.asil.org/insights/volume/22/issue/9/inter-american-court-human-rightsadvisory-opinion-gender-identity-and (accessed on 5 June 2021).

Contesse, Jorge. 2019a. Resisting the Inter-American Human Rights System. Yale Journal of International Law 44: 180-237.

Contesse, Jorge. 2019b. Settling Human Rights Violations. Harvard Journal of International Law 60: 317-75.

Contesse, Jorge. 2019c. Sexual Orientation and Gender Identity in Inter-American Human Rights Law. North Carolina Journal of International Law 44: 353-85.

Council on Hemispheric Affairs. 2012. The Dangers of the Hemisphere Operating without the IACHR's Guidance. Available online: https:/ / www.coha.org/the-dangers-of-the-hemisphere-operating-without-the-iachrs-guidance/ (accessed on 5 June 2021).

Dahlberg, Maija. 2014. Should Social Rights Be Included in Interpretations of the Convention by the European Court of Human Rights? European Journal of Social Security 16: 252-76. [CrossRef]

Dulitzky, Ariel. 2013. Too Little, Too Late: The Pace of Adjudication of the Inter-American Commission on Human Rights. Loyola of Los Angeles International \& Comparative Law Review 35: 131-208.

Epstein, David, Robert Bates, Jack Goldstone, Ida Kristensen, and Sharyn O'Halloran. 2006. Democratic Transitions. American Journal of Political Science 50: 551-69. [CrossRef]

Girardi Fachin, Melina, and Bruna Nowak. 2019. The Joint Declaration to the Inter-American System of Human Rights: Backlash or Contestation? International Journal of Constitutional Law Blog. Available online: http:/ /www.iconnectblog.com/2019/12/the-jointdeclaration-to-the-inter-american-system-of-human-rights-backlash-or-contestation/ (accessed on 5 June 2021).

Grossman, Claudio. 2001. Freedom of Expression in the Inter-American System for the Protection of Human Rights. Nova Law Review 25: 411-42.

Grossman, Claudio. 2012. Challenges to Freedom of Expression within the Inter-American System: A Jurisprudential Analysis. Human Rights Quarterly 34: 361-403. [CrossRef] 
Hampson, Françoise, Claudia Martin, and Frans Viljoen. 2018. Inaccessible Apexes: Comparing Access to Regional Human Rights Courts and Commissions in Europe, the Americas, and Africa. International Journal of Constitutional Law 16: 161-86. [CrossRef]

Helfer, Laurence. 2002. Overlegalizing Human Rights: International Relations Theory and the Commonwealth Caribbean Backlash Against Human Rights Regimes. Columbia Law Review 102: 1832-911. [CrossRef]

Holmund, Caroline. 2014. Why Latin America Is Refusing to Follow the US on Human Rights. Available online: https://www. foreignpolicyjournal.com/2014/04/10/why-latin-america-is-refusing-to-follow-the-us-on-human-rights / (accessed on 5 June 2021).

Inglehart, Ronald, and Christian Welzel. 2005. Modernization, Cultural Change, and Democracy. Cambridge: Cambridge University Press. Inter-American Commission on Human Rights. 2011. The Death Penalty in the Inter-American Human Rights System: From Restrictions to Abolition. Washington, DC: Organization of American States.

Inter-American Commission on Human Rights. 2021. Annual Report 2020. Washington, DC: Organization of American States.

Leijten, Ingrid. 2018. Core Socio-Economic Rights and the European Court of Human Rights. Cambridge: Cambridge University Press.

Martin, Claudia, and Diego Rodriguez-Pinzón. 2015. Strengthening or Straining the Inter-American Human Rights System? In The Inter-American Court of Human Rights: Theory and Practice, Present and Future. Edited by Yves Haeck, Oswaldo Ruiz-Chiriboga and Clara Burbano Herrera. Cambridge: Intersentia, pp. 793-822.

Mason, Ashley. 2012. Violence, Criminal Defamation, and Censorship Laws: Threatening Freedom of Expression in Chile and Ecuador. Law \& Business Review of the Americas 18: 369-99.

Oquendo, Ángel. 2017. The Politicization of Human Rights: Within the Inter-American System and Beyond. New York University Journal of International Law \& Politics 50: 1-73.

Paul, Álvaro. 2016. The Inter-American Commission on Human Rights' Initial Review of Petitions, Its Backlog, and the Principle of Subsidiarity. George Washington International Law Review 49: 19-52.

Picq, Manuela. 2012. Is the Inter-American Commission on Human Rights Too Progressive? Available online: https://www.aljazeera. com/opinions/2012/6/9/is-the-inter-american-commission-of-human-rights-too-progressive (accessed on 5 June 2021).

Przeworski, Adam, R. Michael Alvarez, Michael E. Alvarez, Jose Antonio Cheibub, Fernando Limongi, and Fernando Papaterra Limongi Neto. 2000. Democracy and Development: Political Institutions and Well-Being in the World. Cambridge: Cambridge University Press.

Rivera Juaristi, Francisco. 2013. US Exceptionalism and the Strengthening Process of the Inter-American Human Rights System. Human Rights Brief 20: 19-25.

Ruiz-Chiriboga, Oswaldo. 2013a. Is Ecuador That Wrong? Analyzing the Ecuadorian Proposals Concerning the Special Rapporteurship on Freedom of Expression of the Inter-American Commission on Human Rights. Human Rights Brief 20: 26-33. [CrossRef]

Ruiz-Chiriboga, Oswaldo. 2013b. The American Convention and the Protocol of San Salvador: Two Intertwined Treaties. Netherlands Quarterly of Human Rights 31: 156-83. [CrossRef]

Shelton, Dinah, and Alexandra Huneeus. 2015. In re Direct Action of Unconstitutionality Initiated Against the Declaration of Acceptance of the Jurisdiction of the Inter-American Court of Human Rights. American Journal of International Law 109: 866-72. [CrossRef]

Shelton, Dinah. 2015. The Rules and Reality of Petition Procedures in the Inter-American Human Rights System. Notre Dame Journal of International \& Comparative Law 5: 1-28.

Soley, Ximena, and Silvia Steininger. 2018. Parting Ways or Lashing Back? Withdrawals, Backlash, and the Inter-American Court of Human Rights. International Journal of Law in Context 14: 237-57. [CrossRef]

Udombana, Nsongurua. 2003. So Far, So Fair: The Local Remedies Rule in the Jurisprudence of the African Commission on Human and Peoples' Rights. American Journal of International Law 97: 1-37. [CrossRef]

Warbrick, Colin. 2007. Economic and Social Interests and the European Convention on Human Rights. In Economic, Social, and Cultural Rights in Action. Edited by Mashood Baderin and Robert McCorquodale. Oxford: Oxford University Press, pp. 241-56.

Wilson, Richard. 2002. The United States' Position on the Death Penalty in the Inter-American Human Rights System. Santa Clara Law Review 42: 1159-90.

Yerima, Timothy. 2011. Comparative Evolution of the Challenges of African Regional Human Rights Courts. Journal of Politics $\mathcal{E}$ Law 4: $120-27$.

Zschirnt, Simon. 2017. Is the Inter-American Human Rights System Biased? A Quantitative Analysis of Regional Human Rights Litigation in the Americas. International \& Comparative Law Review 17: 51-81. 